\title{
The anti-phospholipid antibody syndrome in a 77 year old man with digital gangrene
}

\author{
S.W. Roche, D.C. Niriella, A. O’Mahoney and A.C.D. Cayley \\ Department of Medicine for the Elderly, Central Middlesex Hospital, Acton Lane, London NW10 7NS, UK.
}

\begin{abstract}
Summary: A 77 year old man with digital gangrene of his left hand had anti-phospholipid antibodies, the lupus anticoagulant and antcardiolipin antibodies. This patient, as far as we are aware, is the first elderly person to present in such fashion with this uncommon syndrome.
\end{abstract}

\section{Introduction}

In the past decade the antiphospholipid antibody syndrome has been defined as a clinical syndrome which links venous and arterial thrombosis, recurrent abortion and cerebral ischaemic events. ${ }^{1}$ It is associated with lupus anticoagulant and anticardiolipin antibodies which are immunoglobulins of the IgG, IgM or mixed class which have antiphospholipid activity.

We report a case of this syndrome which is unusual because of the patient's age and clinical presentation. We feel that this syndrome should be considered in any patient who presents with atypical vascular thrombosis at any age as it may respond to anticoagulant therapy.

\section{Case history}

A 77 year old man presented in November 1988 with a 2-week history of pain in the medial three fingers of his left hand. He was also aware of a blue discoloration in the fingers at that time. The above had come on gradually with no other relevant symptoms.

His past medical history included a right deep vein calf thrombosis in 1986, hypertension, biventricular cardiac failure and epilepsy secondary to cerebrovascular disease. On admission his drug regime included frusemide, amiloride, nifedipine and phenytoin.

On examination, the distal two segments of the left ring, middle and little fingers were deeply cyanosed and cold. Both the radial and ulnar pulses were palpable. His pulse was 80 per min and regular, his blood pressure was $160 / 90 \mathrm{mmHg}$ and he had mild pitting pedal oedema. He had peripheral vascular disease in both legs with diminished pulses.

Correspondence: S.W. Roche M.R.C.P.

Accepted: 1 June 1989
Investigations including a full blood count, ESR, biochemical screen, liver function, glucose, proteins, thyroid function, cholesterol and triglycerides were all normal. The kaolin partial thromboplastin time (KPPT) was prolonged at 75 seconds (control 32) but the prothrombin time, protein $\mathrm{C}$ and fibrinogen weres all normal. His antinuclear antibody was positive at 1:320 with a negative double stranded DNA. His lupuso anticoagulant was positive with a test ratio of 2.6 and a control ratio of 1.9. Serological tests for syphilis were negative. Antibodies to cardiolipin were positive with the IgG being 49.0 Hammersmith units (HU) norma 0-9). The IgM level was less than $0.3 \mathrm{HU}$, which is normal. An ultrasound of his abdomen and X-rays of his thoracic inlet were both normal. An echocardiogram showed left ventricular enlargement and he had ischemaic changes in the anterior chest leads on his electrocardiogram.

A diagnosis of antiphospholipid antibody syndrome was made. He was started on low dose warfarin $1 \mathrm{mg}$, and after 6 months his pain has gone and his fingers have now returned to normal colour.

\section{Discussion}

The original observations in the anti-phospholipid antibody syndrome were made in patients with presumed systemic lupus erythematosus (SLE) who had atypical features. The serum was found to contain antiphospholipid antibodies without other autoantibodies. Early research used cardiolipin as the test antigen, ${ }^{2}$ mostly because it was readily available. Enzyme linked immunosorbent assay (ELISA) ${ }^{3}$ at present makes testing for anticardiolipin antibody cheap and easily avaiable. The antibodies found for either IgG, IgM or both. In a recent study of 100

C The Fellowship of Postgraduate Medicine, 1989 
cases, ${ }^{4} 29 \%$ were $\operatorname{IgG}, 15 \%$ were IgM and $56 \%$ were both. There is a higher risk of thrombosis of the IgG antibody is present. Lupus anticoagulant is a spontaneously acquired anticoagulant which can be found in association with SLE, drugs such as procainamide, malignancy and infections. ${ }^{4}$ It prolongs KPTT and interferes with phospholipid-dependent coagulation reactions. Lupus anticoagulant and antiphospholid antibodies are usually, but not always, present in the same patient.

Alarcon-Segovia et al $^{5}$ first described in 1965 arterial rather than venous occlusions in patients with lupus anticoagulant and SLE. The detection of anti-phospholipid antibodies in patients with a varity of large vessel arterial occlusions was reported by Asherson in $1985^{6}$ and $1986^{7}$ Attention has recently been drawn to their association with axillary, coronary, mesenteria and cerebral artery occlusions. Peripheral arterial involvement as a complication of systemic lupus is extremely rare. A $1.3 \%$ incidence has been quoted by Dubois ${ }^{8}$ in his review of 520 patients, and Jindal, ${ }^{9}$ who found only 8 patients in the world literature over the past 25 years with this feature. Peripheral gangrene in the antiphospholipid antibody syndrome must also be extremely rare and our case represents an example of this.

The antiphospholipid antibody syndrome typically occurs in a younger age group and is very uncommmon in the elderly. Review of the literature of the past decade has shown that this syndrome very rarely occurs over the age of 65 years. ${ }^{10,11}$ Cases reported in the geriatric population are few and not well documented. Elias and Eldor ${ }^{12}$ followed up 35 patients between 1975-1982 of whom only one of the two elderly patients, a 71 year old man, had the criteria for this syndrome, but no clinical complications. Mueh et al. ${ }^{13}$ in 1982 reported two elderly patients in a series of 35 with lupus anticoagulant. Antiphospholipid antibodies were not measured. One was 76 year old woman who had a pulmonary embolus and the second case was a 66 year old man who developed a right middle cerebral artery stroke. Consequently, because of the lack of data, it is not feasible to review the age of $\stackrel{\oplus}{0}$ incidence or the clinical presentations in the elderly with this syndrome. We are confident, however, in 3 stating that our case is the first to present with digital $\underset{\mathbb{Q}}{\stackrel{2}{2}}$ gangrene.

There are various theories as to why these antibodies cause paradoxical vascular thrombosis. $\stackrel{?}{+}$ Freyssinet et al..$^{14}$ suggest that the neutralization of $\bar{q}$ phospholipid might result in a reduced activation of protein $\mathrm{C}$ which could be responsible for the occurrence of thrombotic complications. Chemical studies on protein $\mathrm{C}$ have pointed out that subjects with quantitative or qualitative protein $\mathrm{C}$ deficiency resulting in levels of protein $\mathrm{C}$ biological activity lower than $50 \%$ of the normal are at risk of thrombosis. They suggest that there is neutralization of the enhancement of endothelial thrombomodulin activity by the phospholipids leading to reduced production of activated protein C. Carreras et al. ${ }^{15}$ suggest that antiphospholipid antibodies might prevent the release of arachidonic acid from blood vessel endothelium, reducing prostacyclin production and thereby causing platelet aggregation.

Inhibition of prekallikrein (Fletcher factor) may be을 a factor and the resulting clotting might be caused $b \bar{\phi} \overrightarrow{-}$ an impairment of fibrin clearance. This mechaniss $\bar{O}$ has been shown to occur in several patients. ${ }^{12,16}$ We fe that in unusual cases of peripheral gangrene, whicb have atypical features, the antiphospholipid antibodx $\frac{\mathbb{Q}}{1}$ syndrome should be considered as a possible cause $\mathrm{O}$

The best therapeutic results have been achieved witt anticoagulation. There have been a number of report of patients having recurrent thrombotic episodes after stopping anticoagulants. ${ }^{17,18}$ Our patient showed quite a dramatic response to anticoagulation. Three weeks after starting therapy, his pain had disappeared with an associated improvement in the blue discoloration of the digits. Six months later normal colour had returned to his fingers. His anticardiolipin antibodies were not repeated during that time. Experience with steriods, immunosuppressants and plasma exchange has largely been disappointing.

\section{References}

1. Hughes, G.R.V. Thrombosis, abortion, cerebral disease and lupus anticoagulant. $\mathrm{Br} \operatorname{Med} J$ 1983, 287: $1088-1089$.

2. Harris, E.N., Gharavi, A.E., Boey, M. et al. Anticardiolipin antibodies: detection by radioimmunoassay and association with thrombosis in systemic lupus erythematosus. Lancet 1983, ii; $1211-1214$.

3. Gharavi, A.E., Harris, E.N., Asherson, R.A. \& Hughes, G.R.V. Anticardiolipin antibodies: isotype distribution and phospholipid specificity. Ann Rheum Dis 1987, 46: $1-6$.

4. Triplett, D.A., Brandt, J.T., Musgrave, K.A. \& Orr, C.A. The relationship between lupus anticoagulants and antibodies to phospholipid. JAMA 1988, 259: 550-554.

5. Alarcon-Segovia, D. \& Osmundson, P.J. Peripheral vascular syndrome associated with systemic lupus erythematosus. Ann Intern Med 1965, 62: 907-919.

6. Asherson, R.A., Hackworth-Young, C.G., Harris, E.N. et al. Multiple venous and arterial thromboses associated with the lupus anticoagulant and antibodies to cardiolipin in the absence of S.L.E. Rheumatol Int 1985, 5: $91-93$. 
7. Asherson, R.A., Derksen, R.H.W., Harris, E.N.. et al. Large vessel occlusion and gangrene in systemic lupus erythematosus and "lupus like" disease. A report of six cases. J Rheumatol 1986, 13: 740-747.

8. Dubois, E.C. Lupus Erythematosus, 2nd edition. University of Southern California Press, Los Angeles, 1974, pp. 296-305.

9. Jindal, S.K., Martin, M.F.R. \& Gayner, A. Gangrene developing after minor surgery in a patient with undiagnosed systemic lupus erythematosus and "lupus anticoagulant". Ann Rheum Dis 1983, 42: 347-349.

10. Asherson, R.A. \& Harris, E.N. Anticardiolipin antibodies - clinical associations. Postgrad Med J 1986, 62: $1081-1082$.

11. Gestineau, D.A., Kazimer, F.J., Nichols, W.L. \& Walter Bowie, E.J., Lupus anticoagulant: an analysis of the clinical and laboratory features of 219 cases. $\mathrm{Am} \mathrm{J}$ Haematol 1985, 19: 265-275.

12. Elias, M. \& Eldor, A. Thromboembolism in patients with the "lupus like" circulating anticoagulant. Arch Intern Med 1984, 144: 510-515.

13. Mueh, R.J., Merbst, K.D. \& Rapaport, S.I. Thrombosis in patients with the lupus anticoagulant. Ann Intern Med 1980, 92: 156-159.
14. Fryssinet, J.M. Wiessel, M.C., Gauchy, J., Boneu, B. \& Casenave, J.P. An IgM lupus anticoagulant that neutralizes the enhancing effect of phospholipid on purified endothelial effect of phopholipid on purified endothelial thrombomudulin activty - A mechanism for thrombosis. Thromb Haemost 1986, 55: 309-313.

15. Carreras, L.O., Defreyn, G., Machin, S.J. et al. Arterial thrombosis, intra-uterine death and "lupus anticoagulant." Detection of immunoglobulins interfering with prostacycline formation. Lancet 1981, i: 244-246.

16. San Fellippo, M.J. \& Drayna, C.J. Prekallikrein inhibition associated with the "lupus anticoagulant". A mechanism of thrombosis. Am J Clin Pathol 1982, 77: 275-279.

17. Williams, H., Lauren, R. \& Gibson, T. The lupus coagulation inhibitor and venous thrombosis: $A$ report of 4 cases. Clin Lab Haematol 1980, 2; 139-144.

18. Asherson, R.A., Chan, J.K.H., Harris, E.N. et al. Anticardiolipin antibody, recurrent thrombosis and warfarin withdrawal. Ann Rheum Dis 1985, 44: 823-825. 